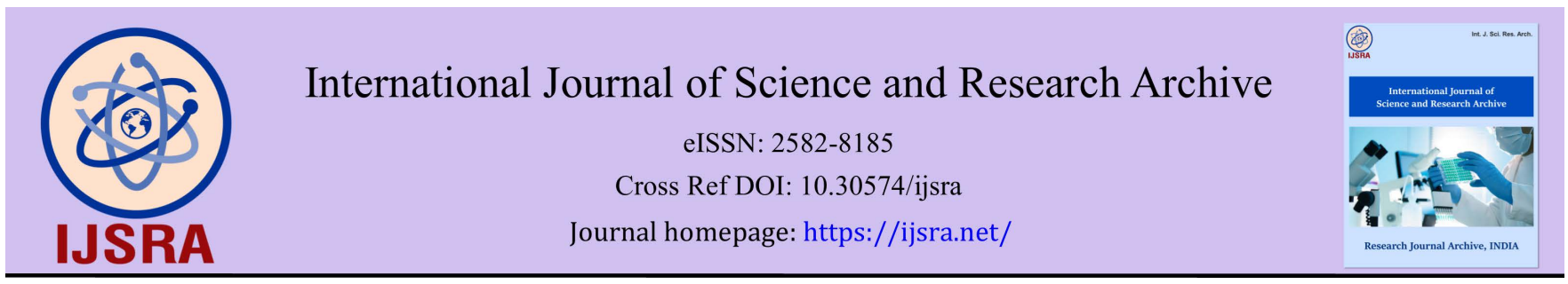

(RESEARCH ARTICLE)

\title{
Antimicrobial and phytochemical evaluation of Datura Stramonium (Jimsonweed) on selected microorganisms
}

\author{
Joy Nkeiruka Dike-Ndudim *, Chiletam Nwadiuto Amadi and Chizaram Winners Ndubueze \\ Department of Medical Laboratory Science, Faculty of Health Sciences, Imo State University, Owerri, Nigeria.
}

International Journal of Science and Research Archive, 2021, 02(02), 245-256

Publication history: Received on 13 May 2021; revised on 20 June 2021; accepted on 22 June 2021

Article DOI: https://doi.org/10.30574/ijsra.2021.2.2.0084

\begin{abstract}
The purpose of this work was to determine the antibacterial and antifungal activities of Datura stramonium on selected microorganisms, and to evaluate its phytochemical properties. The dry and wet leaves of D. stramonium were collected, extracted using ethanol and water, and assessed for antibacterial and antifungal activities at different concentrations (25mg, $12.5 \mathrm{mg}, 6.25 \mathrm{mg}$, and $3.12 \mathrm{mg}$ ) by disc diffusion method. The clinical isolates of Staphylococcus aureus, Streptococcus pyogenes, Escherichia coli, Salmonela typhi, Aspergillus fumigatus and Candida albicans were used. The highest zone of inhibition for bacteria was shown with ethanolic dry extract (11.3 \pm 3.4$)$ at $25 \mathrm{mg} / \mathrm{ml}$ and the lowest with aqueous dry extract $(4.0 \pm 1.4)$ at $25 \mathrm{mg} / \mathrm{ml}$ against Escherichia coli. The highest zone of inhibition for fungi was shown with ethanolic dry extract $(10 \pm 1.4)$ at $25 \mathrm{mg} / \mathrm{ml}$ against Aspergillus fumigatus and the lowest was with ethanolic wet extract $(2.0 \pm 0.0)$ at $25 \mathrm{mg} / \mathrm{ml}$ against Candida albican. The phytochemical analysis result showed the presence of tannin (1.757\%), phenol (1.149\%), flavonoid (6.325\%), alkaloid (8.552\%), phytate (2.671\%), and hydrogen cyanide (4.175\%). The chromatographic analysis showed the presence of over 40 elements with the highest as hydrazine (41\%) and methyl hydrogen disulphide (41\%). In this study, D. stramonium leaf extracts showed significant antibacterial and antifungal activities due to the presence of the phytochemical and bioactive compounds. This upholds the native utility of this plant to treat bacterial and fungal infections. Conclusively, this plant would serve as treatment alternatives for infections and basis for sources of antimicrobial agent.
\end{abstract}

Keywords: Datura stramonium; Antimicrobial; Jimson weed; Extracts; Phytochemicals; Clinical Isolates

\section{Introduction}

Datura stramonium is a binomial name for a plant commonly known as Jimsonweed. It is also known as thorn apple, Jamestown or devil's trumpet in English and Nchuagwo in Igbo and also by other different international and local names. It is a foul-smelling, erect and freely branching annual herb that forms a bush up to 60 to $150 \mathrm{~cm}$ ( 2 to $5 \mathrm{ft}$ ) tall with long, thick, fibrous and white root. The stem splits off continually into branches, and each split gives rise to a leaf and a single, erect flower [1]. The leaves are about 8 to $20 \mathrm{~cm}$ (3-8 in) long, smooth, toothed, soft, and irregularly swollen with the upper surface of the leaves, darker green than the bottom which is lighter green. The leaves have a bitter and nauseating taste, which is imparted to extracts of the herb, and remains even after the leaves have been dried [2]. The flowers are trumpet-shaped, white to creamy or mauve, and barely open completely. The egg-shaped and walnut-sized seed capsule is 3 to $8 \mathrm{~cm}$ (1-3 inches) in diameter and either covered with spines or hairless. At maturity, it splits into four chambers, each with dozens of small, black seeds [3]. Though it has been objected by several schools, it is stipulated to be native to Central America and used by Algonquin Indians in Eastern North America as a hallucinogen and intoxicant. But presently, it is common in several places and can be seen growing along roadsides, railways, residential setting, disturbed land, wasteland, fallow land, crops, grazing land, drainage ditches, woodland edges, lowlands, gullies and dry riverbeds, abandoned cattle yards and on river flats. One popular thought suggests that this plant does not only

\footnotetext{
* Corresponding author: Joy Nkeiruka Dike-Ndudim

Department of Medical Laboratory Science, Faculty of Health Sciences, Imo State University, Owerri, Nigeria. 
occur indigenously in Southern Africa, but also on other areas of the world and was applied by Red Indians for many years as euphoric agent and as therapeutic agent in Great Britain. The plant ingredients are widely used in folkloric medicine in the Caribbean and other parts of the world and serves as herbal remedy given to pregnant mothers with asthmatic complaints. However, over dosage can result in severe toxicity.

Habitually, Jimsonweed is mainly found in warm-temperate and subtropical areas, in open surroundings and grows rapidly on fertile soils and regions with abundant rainfall though they can also survive on sandy meadows and are known as aggressive colonizers of agricultural fields and compete powerfully with crops in various parts of the world. As a weed in more than 100 countries, D. stramonium is considered by Holm et al. [4] to be more widespread than even Cyperus rotundus which is ranked as the world's worst weed.

Generally, medicinal plant have gained recognition worldwide due to the affordability, reliability, accessibility and low side effects in therapeutic use and has increase in demand in both developed and rural areas [5]. Due to the mutagenic characteristics of the bacterial genome, transformation of bacterial cells and rapid multiplication, several diseasecausing microorganisms keep evolving tactics and immunity to multiple antibiotics. In the prevention, diagnosis and treatment of disease, control of microorganisms is important and presently, many microbial diseases like tuberculosis, dengue fever, AIDS have turned out to be challenging and worrisome to the modern medical world and the infectious diseases in the past ten years have been recorded as the cause of obliteration of several lives all through the world, mostly in the developing countries [6]. Several synthetic antibiotics control the growth and development of microorganisms effectively, but they are highly toxic at their optimum dosage level as many of these modern treatment patterns have been constantly facing problems associated with side effects. Among many proposed strategies, a good understanding of plants offers the potential of developing potent broad spectrum antibiotics. In addition, it has been known among many proposed strategies that a fine understanding of plants proffers the possibility of developing potent broad spectrum antibiotics. Thousands of medicinal plants constitute about $10 \%$ of the entire flora [7] and for several years, the bulk of these plant materials have been used by the local community as an alternative solution to treat many diseases. However many of them are still unexplored and not well characterised scientifically [8]. Hence, this research was set out to test and evaluate the antimicrobial activities of Datura stramonium.

Jimsonweed may be an exceedingly popular plant in several sites, but it is massively under researched and contradicted. It is not uncommon even among plant users to refer to it as snake repellent without any other information about the name, mode of action, antimicrobial properties and toxicity, hence, the challenge on the usage, dosage and effect of the plant on microbial life. Moreover, with a prior knowledge that a good understanding of plants proffers the possibility of developing potent broad spectrum antibiotics, it becomes imperative to study the jimsonweed in relation to its component and antimicrobial profile. Therefore, this work is aimed at determining the antibacterial and antifungal activities of Jimsonweed against selected microorganisms, the phytochemical property and chemical content of the plant through chromatography.

\section{Material and methods}

\subsection{Sample Collection}

The leaves of Datura stramonium were collected from various fields of different areas in Iho-dimeze town and confirmed in the Department of Agricultural Science, Imo State University. Some of the leaves were rinsed and dried at room temperature for 21 days, while some were rinsed and shredded. The bacterial and fungal cultures were collected from Federal Medical Centre (F.M.C.), Owerri, maintained on nutrient agar and Sabourad Dextrose Agar (SDA) medium respectively and stored at temperature of $4^{\circ} \mathrm{C}$ for few hours.

\subsection{Preparation of Plant Extract}

The dried leaves were ground to a fine powder using an electronic blender, while the wet shredded leaves were immediately pounded to a paste. Each of the $50 \mathrm{~g}$ of the powdered sample and $50 \mathrm{~g}$ of the paste sample were soaked in $400 \mathrm{ml}$ of ethanol and water respectively for 48 hours. The homogenized plant extracts were filtered out using Whatman No.1 filter paper, prepared using Soxhlet apparatus and then the filtrate evaporated using rotary evaporator. The extracts were collected in sterile screw-cap bottles and stored in refrigerator at $4^{\circ} \mathrm{C}$ according to Nagesh and Samreen [9].

\subsection{Confirmation of Test Organisms}

Standard Staphylococcus aureus, Streptococcus pyogenes, Escherichia coli, Salmonella typhi, Aspergillus fumigatus and Candida albicans were collected and confirmed by the Microbiology Unit, Federal Medical Centre, Owerri. 


\subsection{Antimicrobial Activity of the Crude Extract}

Antimicrobial activity of the crude extract was determined by Disc diffusion method on Nutrient Agar and Sabourad Dextrose Agar media using the method described by Satdive et al, [10]. Stock solution was prepared by mixing $25 \mathrm{mg}$ of the crude extracts of ethanol and water dissolved in $1 \mathrm{ml}$ of Dimethyl sulfoxide (DMSO). Several discs were prepared by perforating Whatman filter paper and immersed in different dilutions of the extracts; 20 discs were immersed in $0.2 \mathrm{ml}$ of $25 \mathrm{mg} / \mathrm{ml}, 12.5 \mathrm{mg} / \mathrm{ml}, 6.25 \mathrm{~g} / \mathrm{ml}, 3.12 \mathrm{mg} / \mathrm{ml}$, and $1.56 \mathrm{mg} / \mathrm{ml}$ each. They were left overnight at room temperature, placed on petri dishes and dried in an oven at $45^{\circ} \mathrm{C}$. Agar was aseptically prepared and then labelled. The test organisms (bacteria and fungi) were smeared on the appropriate media and the disc placed on the agar using sterile forceps. The media plates were incubated at $37^{\circ} \mathrm{C}$. Zones of inhibition were examined, measured and recorded $[11,12]$.

\subsection{Determination of Minimum Inhibitory Concentration (M.I.C)}

$0.5 \mathrm{ml}$ of the different concentrations $(25 \mathrm{mg} / \mathrm{ml}, 12.5 \mathrm{mg} / \mathrm{ml}, 6.25 \mathrm{mg} / \mathrm{ml}, 3.12 \mathrm{mg} / \mathrm{ml}$, and $1.56 \mathrm{mg} / \mathrm{ml})$ for all the organisms and for the ethanolic and aqueous extracts were pipetted into test tubes. For each set, a suspension of the organism was inoculated into the respective tubes and was incubated at $37^{\circ} \mathrm{C}$ for 24 hours. The lowest concentration which inhibited the growth of respective organism (interpreted by turbidity) was taken as MIC.

\subsection{Minimum Bactericidal Concentration (MBC)}

To measure MBC, the broth in the tubes without visible turbidity in MIC were streaked on agar plates and incubated overnight at $37^{\circ} \mathrm{C}$.

\subsection{Phytochemical Analysis}

The phytochemical analysis was carried out on the ethanol extract using standard procedures to identify the phytochemical constituents according to Yadav and Munin [13].

\subsection{Qualitative Analysis}

\subsubsection{Determination of saponins}

$0.5 \mathrm{~g}$ of the sample was separately stirred in a test tube, foaming which persisted on warming was taken as evidence for the presence of saponins.

\subsubsection{Determination of tannins}

$0.5 \mathrm{~g}$ of the extract was separately stirred in a test tube with $10 \mathrm{ml}$ of distilled water and then filtered. Two drops of $5 \%$ Iron III Chloride was added. Blue-black or blue-green colouration or precipitate indicated the presence of tannins.

\subsubsection{Determination of alkaloids}

$0.5 \mathrm{~g}$ of the sample was dissolved with $5 \mathrm{ml} 1 \%$ hydrochloric acid $(\mathrm{HCl})$. Filtrate was treated with Dragendroff's reagent. Formation of red precipitate indicated the presence of alkaloids.

\subsubsection{Determination of glycosides}

$1 \mathrm{~g}$ of the sample was introduced into two different beakers and $5 \mathrm{ml}$ of sulphuric acid added while $5 \mathrm{ml}$ of water was added to the other beaker. The two beakers were heated for 3 minutes and the contents filtered into labelled test tubes. The filtrate was made alkaline with $0.5 \mathrm{ml}$ of sodium hydroxide was allowed to stand for three minutes. The presence of reddish brown precipitate in the filtrate was a positive reaction for glycosides.

\subsubsection{Determination of flavonoids}

A piece of magnesium ribbon and $5 \mathrm{ml}$ of concentrated hydrochloric acid was added to $1 \mathrm{ml}$ of the extract. Colours ranging from orange to red indicated flavones, red to crimson, flavonols and crimson to magenta, flavonones.

\subsubsection{Determination of phenols}

Four drops of ferric chloride solution was added to $1 \mathrm{ml}$ of the extract in a test tube. Formation of bluish black colour indicated the presence of phenols. 


\subsubsection{Determination of carbohydrates}

To $1 \mathrm{ml}$ of the filtrate, $5 \mathrm{ml}$ of Benedict's reagent was added. The mixture was heated and appearance of red precipitate indicated the presence of reducing sugar [14].

\subsubsection{Chromatographic analysis}

For this analysis, $50 \mu \mathrm{l}$ of ethanolic extract of Datura stramonium was aspirated and plunged into the sample inlet which carried the sample all through the other compartments. After a turnaround time of 27 minutes, the spectra was displayed on the connected computer and analyzed, peak after peak, compound after another.

\subsubsection{Data Analysis}

The data from the study were analyzed and the results presented as mean standard deviations. Analysis of variation (ANOVA) was employed to define the significant differences between the zones of inhibition. The statistical significance was determined when $P$ value is $\leq 0.05$.

\section{Results}

\subsection{Antimicrobial Effects of $D$. stramonium Leaf Extracts on Selected Microorganisms}

Table 1 shows the result of ethanolic dry leaf extract with the highest mean zone of inhibition is $16.3 \pm 3.4(25 \mathrm{mg} / \mathrm{ml})$ against Escherichia coli and the lowest as $0.7 \pm 0.6(3.12 \mathrm{mg} / \mathrm{ml})$ against Salmonella typhi while Aspergillus fumigatus was inhibited at a mean zone of $16 \pm 1.4(25 \mathrm{mg} / \mathrm{ml})$ as the highest and $3.3 \pm 2.9(6.25 \mathrm{mg} / \mathrm{ml})$ as the lowest (for bacteria and fungi respectively). There was no inhibitory activity against Streptococcus pyogenes, Escherichia coli, Candida albicans and Aspergillus fumigatus at $3.12 \mathrm{mg} / \mathrm{ml}$. The positive control drug (ciprofloxacin) showed the highest zone of inhibition against Streptococcus pyogenes at $23.6 \pm 1.0$ and the lowest against Escherichia coli at 10.0 \pm 0.0 , while Candida albican showed 20.7 \pm 1.3 and Aspergillus fumigatus at 19.0 \pm 0.0 .

Table 1 Mean \pm zone of inhibition of the ethanolic extract of dried leaves of $D$. stramonium at different concentrations against the selected test bacteria and fungi

\begin{tabular}{|l|c|c|c|c|c|c|}
\hline \multicolumn{7}{|c|}{ Mean zone of inhibition in mm \pm S. D } \\
\hline & \multicolumn{7}{|c|}{ Ethanolic dry leaf extract $(\mathbf{m g} / \mathbf{m l})$} & \multicolumn{2}{c|}{ Control Drugs } \\
\hline Test organism & 25 & 12.5 & 6.25 & 3.12 & Ciprofloxacilin & Fluconazole \\
\hline SS. aureus & $12.3 \pm 0.9$ & $6.0 \pm 2.8$ & $3.3 \pm 2.2$ & $3.0 \pm 0.0$ & $22.0 \pm 2.2$ & - \\
\hline S. pyogenes & $10.6 \pm 1.2$ & $6.3 \pm 4.2$ & $1.0 \pm 1.4$ & $0.0 \pm 0.0$ & $23.6 \pm 1.0$ & - \\
\hline E. coli & $16.3 \pm 3.4$ & $7.0 \pm 3.3$ & $1.6 \pm 2.6$ & $0.0 \pm 0.0$ & $20.0 \pm 0.0$ & - \\
\hline S. typhi & $12.0 \pm 4.3$ & $7.3 \pm 2.0$ & $2.3 \pm 2.2$ & $0.7 \pm 0.6$ & $21.3 \pm 1.3$ & - \\
\hline C. albicans & $14.6 \pm 2.0$ & $5.7 \pm 0.4$ & $4.7 \pm 0.4$ & $0.0 \pm 0.0$ & - & $20.7 \pm 1.3$ \\
\hline A. Fumigatus & $16.0 \pm 1.4$ & $6.3 \pm 2.0$ & $3.3 \pm 2.9$ & $0.0 \pm 0.0$ & - & $19.0 \pm 0.0$ \\
\hline
\end{tabular}

Table 2 shows the result of ethanolic fresh leaf extract where the highest mean zone of inhibition is $10.7 \pm 2.6 \mathrm{~mm}$ $(25 \mathrm{mg} / \mathrm{ml})$ against Streptococcus pyogenes and the lowest as $0.7 \pm 0.9 \mathrm{~mm}(3.12 \mathrm{mg} / \mathrm{ml})$ against Salmonella typhi.

Table 3 shows the result of aqueous dry leaf extract, where the highest mean zone of inhibition is $9.3 \pm 3.1$ ( $25 \mathrm{mg} / \mathrm{ml}$ ) against Streptococcus pyogenes and the lowest as $0.7 \pm 0.9(3.12 \mathrm{mg} / \mathrm{ml})$ against Salmonella typhi. Other microorganisms showed no zone of inhibition at $3.12 \mathrm{mg} / \mathrm{ml}$. Candida albican was inhibited only at mean zones of $3.7 \pm 0.9(25 \mathrm{mg} / \mathrm{ml})$ and $2.7 \pm 0.9(12.5 \mathrm{mg} / \mathrm{ml})$. Aspergillus fumigatus showed no zone of inhibition. 
Table 2 Mean zone of inhibition of the ethanolic wet extract of D. stramonium at different concentrations against the selected test bacteria and fungi

\begin{tabular}{|l|c|c|c|c|c|c|}
\hline \multicolumn{7}{|c|}{ Mean zone of inhibition in mm \pm SD } \\
\hline & \multicolumn{7}{|c|}{ Ethanolic wet leaf extract $(\mathbf{m g} / \mathbf{m l})$} & \multicolumn{2}{c|}{ Positive Control Drugs } \\
\hline Test organism & 25 & 12.5 & 6.25 & 3.12 & Ciprofloxacilin & Fluconazole \\
\hline S. aureus & $8.7 \pm 2.5$ & $2.3 \pm 3.3$ & $1.7 \pm 1.7$ & $0.0 \pm 0.0$ & $22.0 \pm 2.2$ & - \\
\hline S. pyogenes & $10.7 \pm 2.6$ & $6.3 \pm 0.4$ & $2.7 \pm 3.1$ & $0.0 \pm 0.0$ & $23.6 \pm 1.0$ & - \\
\hline E. coli & $9.0 \pm 0.0$ & $2.7 \pm 0.4$ & $1.3 \pm 0.9$ & $0.0 \pm 0.0$ & $20.0 \pm 0.0$ & - \\
\hline S. typhi & $7.7 \pm 2.5$ & $4.7 \pm 3.1$ & $1.7 \pm 1.7$ & $0.7 \pm 0.9$ & $21.3 \pm 1.3$ & - \\
\hline C. albicans & $4.0 \pm 0.0$ & $1.7 \pm 1.7$ & $0.0 \pm 0.0$ & $0.0 \pm 0.0$ & - & $20.7 \pm 1.3$ \\
\hline A. Fumigatus & $12.7 \pm 3.7$ & $5.7 \pm 2.9$ & $2.0 \pm 0.0$ & $0.0 \pm 0.0$ & - & $19.0 \pm 0.0$ \\
\hline
\end{tabular}

Note: Ciprofloxacine; Sensitive $=\geq 21 \mathrm{~mm}$, Resistant $=\leq 15 \mathrm{~mm}$; Fluconazole; Sensitive $=\geq 19 \mathrm{~mm}$, Resistant $=\leq 14 \mathrm{~mm}$

Table 3 Mean \pm zone of inhibition of the aqueous dried leaf extract of $D$. stramonium at different concentrations against the selected test bacteria and fungi

\begin{tabular}{|l|c|c|c|c|c|c|}
\hline \multicolumn{7}{|c|}{ Mean zone of inhibition (mm) \pm S. D } \\
\hline & \multicolumn{7}{|c|}{ Aqueous dry leaf extract(mg/ml) } & \multicolumn{2}{c|}{ Positive Control Drugs } \\
\hline Test organism & 25.0 & 12.5 & 6.25 & 3.12 & Ciprofloxacilin & Fluconazole \\
\hline S. aureus & $6.7 \pm 1.3$ & $2.7 \pm 0.8$ & $3.3 \pm 2.2$ & $0.0 \pm 0.0$ & $22.0 \pm 2.2$ & - \\
\hline S. pyogenes & $9.3 \pm 3.1$ & $3.0 \pm 0.0$ & $1.0 \pm 1.4$ & $0.0 \pm 0.0$ & $23.6 \pm 1.0$ & - \\
\hline E. coli & $4.0 \pm 1.4$ & $3.3 \pm 2.6$ & $1.6 \pm 2.6$ & $0.0 \pm 0.0$ & $20.0 \pm 0.0$ & - \\
\hline S. typhi & $5.7 \pm 1.3$ & $2.3 \pm 1.3$ & $1.7 \pm 1.7$ & $0.7 \pm 0.9$ & $21.3 \pm 1.3$ & - \\
\hline C. albicans & $3.7 \pm 0.9$ & $2.7 \pm 0.9$ & $0.0 \pm 0.0$ & $0.0 \pm 0.0$ & - & $20.7 \pm 1.3$ \\
\hline A. Fumigatus & $0.0 \pm 0.0$ & $0.0 \pm 0.0$ & $0.0 \pm 0.0$ & $0.0 \pm 0.0$ & - & $19.0 \pm 0.0$ \\
\hline
\end{tabular}

Table 4 shows the result of aqueous wet extract. From this table, it can be seen that only Streptococcus pyogenes, Escherichia coli and Salmonella typhi showed zones of inhibition. Staphylococcus auerus showed no zone of inhibition as well as all the fungi (Candida albican and Aspergillus fumigatus).

Table 4 Mean zone of inhibition of the ethanolic dry extract of D. stramonium at different concentrations against the selected test bacteria and fungi

\begin{tabular}{|l|c|c|c|c|c|c|}
\hline \multicolumn{7}{|c|}{ Mean zone of inhibition (mm) \pm S.D } \\
\hline & \multicolumn{7}{|c|}{ Aqueous wet leaf extract (mg/ml) } & \multicolumn{2}{c|}{ Positive Control Drugs } \\
\hline Test organism & 25 & 12.5 & 6.25 & 3.12 & Ciprofloxacilin & Fluconazole \\
\hline S. aureus & $0.0 \pm 0.0$ & $0.0 \pm 0.0$ & $0.0 \pm 0.0$ & $0.0 \pm 0.0$ & $22.0 \pm 2.2$ & - \\
\hline S. pyogenes & $9.7 \pm 1.2$ & $7.0 \pm 0.0$ & $0.0 \pm 0.0$ & $0.0 \pm 0.0$ & $23.6 \pm 1.0$ & - \\
\hline E. coli & $7.7 \pm 1.3$ & $6.7 \pm 2.5$ & $2.7 \pm 0.4$ & $0.0 \pm 0.0$ & $20.0 \pm 0.0$ & - \\
\hline S. typhi & $10.0 \pm 3.3$ & $9.3 \pm 4.5$ & $3.0 \pm 2.2$ & $0.7 \pm 0.4$ & $21.3 \pm 1.3$ & - \\
\hline C. albicans & $0.0 \pm 0.0$ & $0.0 \pm 0.0$ & $0.0 \pm 0.0$ & $0.0 \pm 0.0$ & - & $20.7 \pm 1.3$ \\
\hline A. Fumigatus & $0.0 \pm 0.0$ & $0.0 \pm 0.0$ & $0.0 \pm 0.0$ & $0.0 \pm 0.0$ & - & $19.0 \pm 0.0$ \\
\hline
\end{tabular}

Note: Ciprofloxacine; Sensitive $=\geq 21 \mathrm{~mm}$, Resistant $=\leq 15 \mathrm{~mm}$; Fluconazole; Sensitive $=\geq 19 \mathrm{~mm}$, Resistant $=\leq 14 \mathrm{~mm}$ 
Table 5 shows the Minimum Inhibitory Concentration of ethanolic dried leaf extract of $3.12 \mathrm{mg} / \mathrm{ml}$ against Staphylococcus aureus. For the other bacteria; Streptococcus pyogenes, Escherichia coli and Salmonella typhi, MIC of $12.5 \mathrm{mg} / \mathrm{ml}$ was obtained, while the fungi; Candida albicans and Aspergillus fumigatus both showed MIC of $6.25 \mathrm{mg} / \mathrm{ml}$.

\subsection{Minimum Inhibitory Concentration (MIC)}

Table 5 Minimum Inhibitory Concentration of ethanolic dry extract of Datura stramonium against selected test bacteria and fungi

\begin{tabular}{|l|c|c|c|c|c|}
\hline \multicolumn{7}{|c|}{ Minimum Inhibitory Concentration (mg/ml) } \\
\hline & $\mathbf{2 5}$ & $\mathbf{1 2 . 5}$ & $\mathbf{6 . 2 5}$ & $\mathbf{3 . 1 2}$ & $\mathbf{1 . 5 6}$ \\
\hline Staphylococcus aureus & - & - & - & - & + \\
\hline Streptococcus pyogenes & - & - & + & + & + \\
\hline Escherichia coli & - & - & + & + & + \\
\hline Salmonella typhi & - & - & + & + & + \\
\hline Candida albican & - & - & - & + & + \\
\hline Aspergillus fumigatus & - & - & - & + & + \\
\hline
\end{tabular}

Table 6 shows the Minimum Inhibitory Concentration of ethanolic fresh leaf extract of $6.25 \mathrm{mg} / \mathrm{ml}$ for Streptococcus pyogenes and $12.5 \mathrm{mg} / \mathrm{l}$ for Salmonella typhi. MIC of $25 \mathrm{mg} / \mathrm{ml}$ was shown for Staphylococcus aureus and Escherichia coli. Then, MIC of $12.5 \mathrm{mg} / \mathrm{ml}$ for Aspergillus fumigatus was obtained.

Table 6 Minimum Inhibitory Concentration of ethanolic wet extract of Datura stramonium against selected test bacteria and fungi

\begin{tabular}{|l|c|c|c|c|c|}
\hline \multicolumn{7}{|c|}{ Minimum Inhibitory Concentration (mg/ml) } \\
\hline & $\mathbf{2 5}$ & $\mathbf{1 2 . 5}$ & $\mathbf{6 . 2 5}$ & $\mathbf{3 . 1 2}$ & $\mathbf{1 . 5 6}$ \\
\hline Staphylococcus aureus & - & + & + & + & + \\
\hline Streptococcus pyogenes & - & - & - & + & + \\
\hline Escherichia coli & - & + & + & + & + \\
\hline Salmonella typhi & - & - & + & + & + \\
\hline Candida albican & + & + & + & + & + \\
\hline Aspergillus fumigatus & - & - & + & + & + \\
\hline
\end{tabular}

Table 7 Minimum Inhibitory Concentration of aqueous dried leaf extract of Datura stramonium against selected bacteria and fungi

\begin{tabular}{|l|c|c|c|c|c|}
\hline \multicolumn{7}{|c|}{ Minimum Inhibitory Concentration (mg/ml) } \\
\hline & $\mathbf{2 5}$ & $\mathbf{1 2 . 5}$ & $\mathbf{6 . 2 5}$ & $\mathbf{3 . 1 2}$ & $\mathbf{1 . 5 6}$ \\
\hline Staphylococcus aureus & - & + & + & + & + \\
\hline Streptococcus pyogenes & - & - & + & + & + \\
\hline Escherichia coli & - & - & + & + & + \\
\hline Salmonella typhi & - & + & + & + & + \\
\hline Candida albicans & - & - & + & + & + \\
\hline Aspergillus fumigatus & + & + & + & + & + \\
\hline
\end{tabular}


Table 8 shows the Minimum Inhibitory Concentration of aqueous wet extract of $6.25 \mathrm{mg} / \mathrm{ml}$ against Salmonella typhi and $12.5 \mathrm{mg} / \mathrm{ml}$ for Streptococcus pyogenes and Escherichia coli. Staphylococcus aureus was not inhibited at any concentration, as well as the fungi (Candida albicans and Aspergillus fumigatus).

Table 8 Minimum Inhibitory Concentration of aqueous fresh leaf extract of Datura stramonium on selected test bacteria and fungi

\begin{tabular}{|l|c|c|c|c|c|}
\hline \multicolumn{7}{|c|}{ Minimum Inhibitory Concentration (mg/ml) } \\
\hline & $\mathbf{2 5}$ & $\mathbf{1 2 . 5}$ & $\mathbf{6 . 2 5}$ & $\mathbf{3 . 1 2}$ & $\mathbf{1 . 5 6}$ \\
\hline Staphylococcus aureus & + & + & + & + & + \\
\hline Streptococcus pyogenes & - & - & + & + & + \\
\hline Escherichia coli & - & - & + & + & + \\
\hline Salmonella typhi & - & - & - & + & + \\
\hline Candida albican & + & + & + & + & + \\
\hline Aspergillus fumigatus & + & + & + & + & + \\
\hline
\end{tabular}

\subsection{Minimum Bactericidal Concentration}

Table 9 shows the Minimum Bactericidal Concentration of ethanolic dried leaf extract. The MBC effected at all tested microorganisms was $25 \mathrm{mg} / \mathrm{ml}$ except Salmonella typhi that showed MBC of $12.5 \mathrm{mg} / \mathrm{ml}$.

Table 9 Minimum Bactericidal Concentration of ethanolic dried leaf extract of Datura stramonium against selected bacteria and fungi

\begin{tabular}{|l|c|c|c|c|}
\hline \multicolumn{5}{|c|}{ Minimum Bactericidal Concentration (mg/ml) } \\
\hline & $\mathbf{2 5}$ & $\mathbf{1 2 . 5}$ & $\mathbf{6 . 2 5}$ & $\mathbf{3 . 1 2}$ \\
\hline Staphylococcus aureus & - & + & + & + \\
\hline Streptococcus pyogenes & - & + & + & + \\
\hline Escherichia coli & - & + & + & + \\
\hline Salmonella typhi & - & - & + & + \\
\hline Candida albican & - & + & + & + \\
\hline Aspergillus fumigatus & - & + & + & + \\
\hline
\end{tabular}

Table 10 shows the Minimum Bactericidal Concentration of ethanolic wet extract against Streptococcus pyogenes, Escherichia coli and Aspergillus fumigatus as $25 \mathrm{mg} / \mathrm{ml}$.

Table 10 Minimum Bactericidal Concentration of ethanolic fresh leaf extract of Datura stramonium against selected bacteria and fungi.

\begin{tabular}{|l|c|c|c|c|}
\hline \multicolumn{5}{|c|}{ Minimum Bactericidal Concentration (mg/ml) } \\
\hline & $\mathbf{2 5}$ & $\mathbf{1 2 . 5}$ & $\mathbf{6 . 2 5}$ & $\mathbf{3 . 1 2}$ \\
\hline Staphylococcus aureus & + & + & + & + \\
\hline Streptococcus pyogenes & - & + & + & + \\
\hline Escherichia coli & - & + & + & + \\
\hline Salmonella typhi & + & + & + & + \\
\hline Candida albican & + & + & + & + \\
\hline Aspergillus fumigatus & - & + & + & + \\
\hline
\end{tabular}


Table 11 shows the Minimum Bactericidal Concentration of aqueous dry extract was observed only against Streptococcus pyogenes at $25 \mathrm{mg} / \mathrm{ml}$.

Table 11 Minimum Bactericidal Concentration of aqueous dry extract of Datura stramonium against selected bacteria and fungi

\begin{tabular}{|l|c|c|c|c|}
\hline \multicolumn{5}{|c|}{ Minimum Bactericidal Concentration (mg/ml) } \\
\hline & $\mathbf{2 5}$ & $\mathbf{1 2 . 5}$ & $\mathbf{6 . 2 5}$ & $\mathbf{3 . 1 2}$ \\
\hline Staphylococcus aureus & + & + & + & + \\
\hline Streptococcus pyogenes & - & + & + & + \\
\hline Escherichia coli & + & + & + & + \\
\hline Salmonella typhi & + & + & + & + \\
\hline Candida albicans & + & + & + & + \\
\hline Aspergillus fumigatus & + & + & + & + \\
\hline
\end{tabular}

Table 12 shows the Minimum Bactericidal Concentration of aqueous wet extract was $25 \mathrm{mg} / \mathrm{ml}$ against Salmonella typhi, Streptococcus pyogenes and Escherichia coli.

Table 12 Minimum Bactericidal Concentration of aqueous wet extract of Datura stramonium against selected bacteria and fungi

\begin{tabular}{|l|c|c|c|c|}
\hline \multicolumn{5}{|c|}{ Minimum Bactericidal Concentration (mg/m) } \\
\hline & $\mathbf{2 5}$ & $\mathbf{1 2 . 5}$ & $\mathbf{6 . 2 5}$ & $\mathbf{3 . 1 2}$ \\
\hline Staphylococcus aureus & + & + & + & + \\
\hline Streptococcus pyogenes & - & + & + & + \\
\hline Escherichia coli & - & + & + & + \\
\hline Salmonella typhi & - & + & + & + \\
\hline Candida albican & + & + & + & + \\
\hline Aspergillus fumigatus & + & + & + & + \\
\hline
\end{tabular}

\subsection{Phytochemical Analysis}

Table 13 shows the quantitative phytochemical analysis of $D$. stramonium with the highest quantity as alkaloid (8.550\%) and the lowest as phenol (1.149\%)

Table 13 Quantitative phytochemical analysis

\begin{tabular}{|l|c|}
\hline Compound & Quantity (\%) \\
\hline Tannin & 1.757 \\
\hline Phenol & 1.149 \\
\hline Flavonoid & 6.325 \\
\hline Alkaloid & 8.550 \\
\hline Phytate & 2.671 \\
\hline $\begin{array}{l}\text { Hydrogen } \\
\text { cyanide }\end{array}$ & 4.175 \\
\hline
\end{tabular}




\subsection{Chromatographic Analysis}

The chromatographic analysis of the ethanolic extract of Datura stramonium using gas chromatography-mass spectrometry is shown in table 14. From this table, it can be observed that one peak can have one, two or three compounds at the same retention time. Peak 2 containing methyl hydrogen disulfide and hydrazine has the highest percentage (41\%) and Peak 4 containing thiazole and butanoic acid has the lowest $(0.032 \%)$.

Table 14 Chromatographic analysis of the ethanolic extract of Datura stramonium using gas chromatography-mass spectrometry

\begin{tabular}{|c|c|c|c|}
\hline Peak number & Retention time(minute) & Name & Percentage \\
\hline 1 & 1.342 & Benzene-ethanamine & 3.262 \\
\hline 1 & 1.342 & Bactolin & 3.262 \\
\hline 2 & 1.406 & Methyl hydrogen disulfide & 41.110 \\
\hline 2 & 1.406 & Hydrazine & 41.110 \\
\hline 3 & 2.006 & Cyclohexane & 1.587 \\
\hline 3 & 2.006 & Hexane & 1.587 \\
\hline 4 & 3.147 & Thiazole & 0.032 \\
\hline 4 & 3.147 & Butanoic acid & 0.032 \\
\hline 5 & 3.246 & Cyclohexyl-ethylamine & 0.060 \\
\hline 5 & 3.246 & Benzene-ethanamine & 0.060 \\
\hline 5 & 3.246 & Dextroamphetamine & 0.060 \\
\hline 5 & 3.246 & dl-phenylephrine & 0.060 \\
\hline 5 & 3.246 & Phenylephrine & 0.060 \\
\hline 5 & 3.246 & Thiophene-3-ol & 0.060 \\
\hline 6 & 7.890 & Benzene methanol & 0.041 \\
\hline 6 & 7.890 & 2-iodohistidine & 0.041 \\
\hline 7 & 8.728 & Ethanamine & 0.037 \\
\hline 7 & 8.728 & Amphetamine & 0.037 \\
\hline 8 & 10.020 & 6,9,12-octadecatrienoic acid & 0.061 \\
\hline 8 & 10.020 & Allyl(dimethyl)benzyl oxysilone & 0.061 \\
\hline 9 & 11.091 & 1-hydroxy-4-dimethylhydrazonomethyl & 0.033 \\
\hline 9 & 11.091 & 3-(E)-octen-2-one & 0.033 \\
\hline 10 & 12.092 & Diisopropyl(ethoxy)silane & 0.032 \\
\hline 11 & 13.658 & 2,5-methylene-1-thamnitol & 0.041 \\
\hline 12 & 14.275 & 1-ethoxy-1-methyl-1-silacyclohexane & 0.032 \\
\hline 12 & 14.275 & Adipic acid & 0.032 \\
\hline 13 & 15.113 & 3-ethyl-4-hydroxy-4 & 0.034 \\
\hline 14 & 15.881 & 2,3-0-Benzal-d-mannosan & 0.032 \\
\hline 14 & 15.881 & 2,3-0-Benzal-d-mannosan & 0.032 \\
\hline 15 & 16.553 & Artemiseole & 0.048 \\
\hline 16 & 17.220 & Amphetamine & 0.033 \\
\hline
\end{tabular}


International Journal of Science and Research Archive, 2021, 02(02), 245-256

\begin{tabular}{|c|l|l|c|}
\hline 17 & 17.243 & 9,10-secochola & 0.032 \\
\hline 18 & 17.639 & Benzenamine & 0.069 \\
\hline 18 & 17.639 & Benzene propanoic acid & 0.069 \\
\hline 19 & 20.665 & 4-hydroxy-4-(2-methylcychonex-3-enyl) & 0.044 \\
\hline 19 & 20.665 & Hydrocinnamic acid & 0.044 \\
\hline 20 & 21.602 & 5,7-dodecadiyn-1,2-diol & 0.071 \\
\hline 20 & 21.602 & 3-cyclohexen-1-ol & 0.071 \\
\hline 21 & 22.743 & 3,7,11,15-tetramethyl-2-hexadeen 1-ol & 0.035 \\
\hline 21 & 22.743 & Phytol, acetate & 15.775 \\
\hline 22 & 27.882 & 7-methyl-Z-tetradecen-1-ol acetate & 15.775 \\
\hline 23 & 28.720 & Octadecanoic acid & 1.233 \\
\hline
\end{tabular}

\section{Discussion}

The wide use of Datura stramonium by mainly rural communities is due to its availability and affordability. Herbal medicine generally, is becoming popular and widespread even among urban areas and gaining more attraction and interest.

The knowledge of plant extract and phytochemicals with known antimicrobial potentials can be of great value in therapeutic use. Hence, in this study, the antimicrobial activities using ethanolic and aqueous extracts of different concentrations against human pathogenic microorganisms, the phytochemical constituents and bioactive compounds were conducted. And there was no previous work conducted to validate the leaf extracts of this plant using the model employed in this research. Both ethanolic and aqueous extracts showed antibacterial and antifungal activities against test bacteria and fungi which is supported by previous study of Ilodibia et al., [15]. Ethanolic dry extract showed the highest activities against both bacteria and fungi which indicates ethanol is a better solvent than water and dry leaves give better extraction than wet leaves (this could be as a result of reduced water content and more concentrated content in dry leaves). There were higher antimicrobial activities against bacteria than fungi. This was in tune with the outcome of research by Hadia et al., [16]. The differences between the results may be due to different cell culture types. The extract of $D$. stramonium showed antibacterial activity against $S$. aureus and $E$.coli which is in line with the result obtained by Baynesagne et al., [5]. In a study by Venkanna et al., [17], the crude ethyl acetate extracts of Datura leaves showed good zone of inhibition $(22 \pm 0.5)$ against $S$. aureus. There was antibacterial activity against $S$. pyogenes and $S$. typhi which is in line with the outcome of Benito et al., [18]. There was antifungal activity against $C$. albicans and $A$. fumigatus which corroborates with the work of Hadia et al., [16].

In the phytochemical analysis, saponin, alkaloid, tannin were quantified amongst others. The ethyl acetate present in tannin and alkaloid were also reported by Adebayo, [19] to be active against Escherichia coli. Tannins have been indicted to be responsible for the prevention of microorganism development by precipitating microbial protein and inhibiting nutritional proteins. Saponins were also shown by Fluck [20] to be active antifungal agents and that classes of alkaloids are among the major poisons known. This supports a finding that the plant extract may be useful in chemotherapy of mycotic infections [16]. Antibacterial activity of D. stramonium against Gram positive bacteria in a dose dependent manner has also been reported by Eftekhar et al., [21]. Antimicrobial activity of this plant was due to the phytochemicals present and the secondary metabolites identified in this plant could also be responsible for the antimicrobial activity exhibited by this plant. Artemiosole has antifungal activity, carbamic acid plays a role in Escherichia coli metabolite. Amphetamine, Benzamine, Ethylamine which were bioactive compounds found in the chromatographic analysis of this plant are drugs that can be used for effective medical usage. In a research by Akharaiyi and Boboye [22], antioxidant activity shown by this plant was due to the presence of flavonoids. Hexane which was present in this plant was an utmost antimicrobial potential against resistant microorganisms in a study by Ndayambaje et al., [23]. The result of the phytochemical screening of ethanolic extract of Datura stramonium showed the presence of various phytoconstituents like alkaloids, flavonoids, tannins and saponins which is in line with the outcomes obtained by Samier et al., [24]. These phytoconstituents are known to be biologically active compounds and are responsible for antibacterial, antifungal, antioxidant, anticancer activities [25]. 
The antibacterial and antifungal activities of $D$. stramonium leaf extracts are therefore, due to the presence of fundamental componenets such as flavonoids, tannins, saponins, alkaloids, hexane, artemiosole which also makes Datura stramonium a treasured plant that can be used in the treatment of many ailments.

\section{Conclusion}

This study of the antimicrobial potentials on selected bacteria and fungi and phytochemical content of Datura stramonium (Jimsonweed) is a preamble as a potential source of valuable drugs. Different extracts showed different degrees of antibacterial and antifungal activities against test microbes. Phytochemical and bioactive compounds present in this plant are responsible for the outcome of the result. From this study, the plant can serve as a means of pharmacological importance and therefore, extensive and further studies on the bioactive compounds and their antimicrobial activity should be considered. Similar and different forms of microorganisms, increased concentration of extract, investigation to validate microbial activities against bacteria, fungi and other possible microbes are measures that need to be taken in further research about this plant. This will unfold many wonders and the prospective mine of this plant as a traditional medicine and to find more importance of the yet-to-be explored constituents of the plant.

\section{Compliance with ethical standards}

\section{Acknowledgments}

We are sincerely grateful to our families as well as the staff and students of the Department of Medical Laboratory Science, Imo State University, Owerri, Nigeria, for their support throughout the period of this work.

\section{Disclosure of conflict of interest}

There is no conflict of interest.

\section{References}

[1] Soni KA, Desai M, Oladunjoye M, Skrobot F, Nannapaneni R. Reduction of Listeria monocytogenes in queso fresco cheese by a combination of listericidal and listeriostatic GRAS antimicrobials. International journal of food microbiology. 2012; 155(12): 82-88.

[2] Usha K, Singh B, Praseetha P, Deepa N, Agarwal D, Agarwal R. Antifungal activity of Datura stramonium, Calotropis gigantea and Azadirachta indica against Fusarium mangiferae and floral malformation in mango. European journal of plant pathology. 2009; 124(4): 637-657.

[3] Olofintoye LK, Simon IA, Omoregie OB. Larvicidal properties of Datura stramonium (Jimson weed) and Nicotiana tabaccum extracts against the larvae of (Anopheles and Culex) mosquitoes. African research review. 2011; 5(2): 337-344.

[4] Holm LG, Doll J, Holm E, Pancho JV, Herberger J P. World Weeds: Natural Histories and Distribution. New York: John Wiley \& Sons Inc. 1997.

[5] Baynesagne S, Berhane N, Sendeku W, Ai L. Antibacterial activity of Datura stramonium against standard and clinical isolate pathogenic microorganisms. Journal of Medicinal Plants Research. 2017; 11(31): 501-506.

[6] Sharma RA, Sharma P, Yadav A. Antimicrobial screening of sequential extracts of Datura stramonium. International Journal of Pharmacology. 2013; 5(2): 401-404.

[7] Abreham B, Awokeh G, Birtukan G, Rahel A, Taye M, Workabeba D. Antimicrobial activity of Thymus schimperi Ronninger (Lamiaceae) against standard and clinical isolates of human pathogenic bacteria. Journal of Medicinal Plants Research. 2015; 9(11): 379-384.

[8] Geleta B, Eyasu M, Kebamo A, Mekonnen E, Abebe A. In vitro vasodilatory effect of aqueous leaf extract of Thymus serrulatus on thoracic aorta of Guinea pigs. Asian Pacific Journal of Tropical Biomedical. 2015; 5(1):15-18.

[9] Nagesh M, Samreen A. Antimicrobial Activity of Carica papaya, Piper nigrum and Datura stramonium Plants on Drug Resistant Pathogens Isolated from Clinical Specimens. IOSR Journal of Biotechnology and Biochemistry (IOSR-JBB). 2016; 2(6): 56-61. 
[10] Satdive RK, Chimata R, Namdeo A, Fulzele D. In Vitro Screening for Phytochemical and Antimicrobial Activity of Poisonous Plant Fisus Tseila Roxb. International Journal of Pharmaceutical and Biological Sciences. 2012; 3(12): 213-221.

[11] Espinel-Ingroff A, Dawson K, Pfaller M, et al. Comparative and collaborative evaluation of standardization of antifungal susceptibility testing for filamentous fungi. Antimicrobial Agents and Chemotherapy. 1995; 39:314319.

[12] Okeke MI, Iroegbu CU, Eze EN, Okoli AS, Esimone CO. Evaluation of extracts of the root of Landolphia owerrience for antibacterial activity. Journal of Ethnopharmacology. 2001; 78(2): 119-127.

[13] Yadav RNS, Agarwala M. Phytochemical Analysis of Some Medicinal Plants. Journal of Phytology. 2011; 3(12): 1014.

[14] Harborne JB. Phytochemical methods: A Guide to modern Techniques of Plant Analysis. London: Champman and Hall. 1973.

[15] Ilodibia CV, Ugwu RU, Nwokolo OL, Chukwuma MU, Akachukwu EE. Phytochemical screening, Antifungal and Antibacterial Activity of Aqueous and Ethanolic Leaf and Stem Extracts of Gnetum africanum Welw. Research Journal of Medicinal Plants. 2015; 9(6): 275-283.

[16] Hadia G, Rubina N, Muhammad A, Shazia H, Nabila Y. Antibacterial and antifungal activity of different extracts of Datura stramonium. Journal of Biotechnology and Pharmaceutical Research. 2012; 3(9): 141-148.

[17] Venkanna B, Uma A, Suvarnalaxmi C. Antimicrobial property of Datura stramonium leaf extract against methicillin-resiststant Staphycoccus aureus isolated from urethral and skin suppurative infections. Current trend in Biotechnology and Pharmacy. 2013; 7(3):782-792.

[18] Benito N, Moreno A, Miro JM, Torres A. Pulmonary infections in HIV-infected patients: an update in the 21st century. [Online]. Accessed. 21 March 2015.

[19] Adebayo AC, Oloke JK, Aladesanmi AJ. Antimicrobial activities of the leaf of Eugenia Uniflora. Phytotherapy research. 1989; 3(6): 258-259.

[20] Fluck H. Medicinal Plants and their uses. New York: W. Feulsham and Co. Ltd. 1973.

[21] Eftekhar F, Yousefzadi M, Tafakori V. Antimicrobial activity of Datura innoxia and Datura stramonium. Fitoterapia. 2005; 76(1): 118-120.

[22] Akharaiyi FC, Boboye B. Antibacterial and phyto-chemical evaluation of three medicinal plants. J Nat Prod. 2010; 3: 27-34.

[23] Ndayambaje J, Nteziyaremye B, Ange S. Comparative bacterial inhibition by bioactive extracts from Datura stramonium. Virol Res J. 2018; 2(1):1-5.

[24] Samier A, Prashant A, Sikander D. Phytochemical analysis, antioxidant and antimicrobial activities of methanolic extract of Datura stramonium seeds. International Journal of pharmaceutical sciences and research. 2018; 23205148.

[25] Hossain MA, Nagooru MR. Biochemical profiling and total flavonoids contents of leaves crude extract of endemic medicinal plant Corydyline terminalis L. Kunth. Pharmacognosy Journal. 2011; 3(24): 25-29. 